\title{
FORMULASI KRIM MINYAK BIJI BUNGA MATAHARI SEBAGAI ANTI-ACNE DENGAN GLISERIL MONOSTEARAT DAN SETIL ALKOHOL
}

\author{
Kartiningsih* dan Meilisa \\ Laboratorium Teknologi Farmasi Sediaan Semi Solid dan Cair Fakultas Farmasi \\ Universitas Pancasila, Lenteng Agung, Jakarta Selatan \\ *Email: kartiningsih.kania2@gmail.com
}

\begin{abstract}
ABSTRAK
Minyak biji bunga matahari memiliki kandungan terpenoid dan asam linoleat, sehingga dapat menghambat Propionibacterium acnes dan dapat diformulasikan menjadi sediaan krim. Penelitian ini bertujuan untuk memperoleh formula terbaik dari sediaan krim minyak biji bunga matahari. Minyak biji bunga matahari ditentukan nilai KHM dan didapat hasil sebesar $1,5 \%$. Dilakukan formulasi sediaan krim menggunakan desain faktorial $2^{2}$ dengan variasi konsentrasi gliseril mono stearat dan setil alkohol. Sediaan krim dibuat dengan cara memanaskan fase air dan fase minyak masing-masing pada suhu $70^{\circ} \mathrm{C}$, lalu dicampur dan diaduk sampai terbentuk sediaan krim. Terhadap sediaan dilakukan evaluasi baik secara fisika, kimia, maupun mikrobiologi. Dari hasil evaluasi dilakukan overlaid counter plot untuk mendapatkan formula terbaik sesuai syarat mutu fisika, kimia, dan mikrobiologi. Formula terbaik didapat pada formula III dengan konsentrasi gliserilmonostearat sebesar 9\% dan setil alcohol sebesar 1\%. Dari hasil evaluasi pada formula III didapat sediaan krim berwarna putih, tidak berbau, dan tekstur lembut dengan nilai yield value sebesar 90,77 dyne $/ \mathrm{cm}^{2}$, memiliki ukuran globul sebesar 59,90 $\mu \mathrm{m}$, viskositas sebesar 32705,33 cP dengan sifat alir tiksotropi plastis, kemampuan menyebar sebesar $33,62 \mathrm{~cm}^{2}$, dan $\mathrm{pH}$ sebesar 5,95, dan DDH sebesar 15,28 $\mathrm{mm}$.
\end{abstract}

Kata kunci: minyak biji bunga matahari, Propionibacterium acnes, gliserilmonostearat, setilalkohol, krim, anti-acne.

\begin{abstract}
Sunflower seed oil contains terpenoids and linoleic acid, which can inhibit Propionibacterium acnes (the bacteria that cause acne). This research is to obtain the best formula of the sunflower seed oil as topical cream. The MIC of sunflower seed oil is determined and got the result about $1.5 \%$. Formulation of cream is done using factorial design $2^{2}$ with variation concentration of glycerylmonostearate and cetyl alcohol. Cream is made by heating the water phase and the oil phase respectively at temperature of $70^{\circ} \mathrm{C}$, and then mixed and stirred until it forms a cream. After that, cream is evaluated both in physics, chemistry, and microbiology. The results of the evaluation are plotted to get the best formula of the antiacne cream. The best formula is Formula III with concentration of glycerylmonostearate of $9 \%$ and cetyl alcohol of $1 \%$. From the results of the evaluation, the obtained formula has a white colour, odorless, and soft texture cream with a yield value equal to the value of $90.77 \mathrm{dyne} / \mathrm{cm}^{2}$, has globule size of $59.90 \mu \mathrm{m}$, the viscosity of $32705.33 \mathrm{cP}$ with thixotropic plastis flow, the spreadability amounted to $33.62 \mathrm{~cm}^{2}$, and $\mathrm{pH}$ of 5.95, and inhibition zone diameter of $15.28 \mathrm{~mm}$.
\end{abstract}


Keywords: sunflower seed oil, glycerylmonostearate, cetyl alcohol, cream, anti-acne.

\section{PENDAHULUAN}

Jerawat merupakan penyakit peradangan yang terjadi akibat penyumbatan pada pilosebasea yang ditandai dengan adanya komedo, papul, pastul dan bopeng (scar) pada daerah wajah, leher, lengan atas, dada, dan punggung. Peradangan dipicu oleh bakteri Propionibacterium acnes, Staphylococcus epidermidis dan Staphylococcus aureus.Sudah terdapat produk-produk kosmetik yang dihasilkan untuk menangani masalah jerawat, misalnya antibiotik benzoil peroksida, asam azelat, dan retinoid. Namun, obat-obat ini memiliki efek samping dalam penggunaannya sebagai anti-acne. Hal inilah yang melatarbelakangi penelitian ini untuk mencari alternatif pengobatan yang berasal dari bahan alam yang memiliki efek samping minimal. Salah satu tanaman yang secara empiris dan berdasarkan data ilmiah memiliki khasiat anti jerawat adalah bunga matahari (Helianthus annuus L.).Biji bunga matahari mengandung terpenoid dan asam linoleat yang dapat membantu dalam mencegah dan menghilangkan jerawat. Terpenoid bekerja dengan merusak membran sel bakteri. Asam linoleat bekerja sebagai antiinflamasi, sehingga dapat mengatasi peradangan yang diakibatkan oleh jerawat. Kandungan tersebut dapat diperoleh dalam bentuk minyak dengan cara pengepresan dingin (cold press) pada biji bunga matahari. Penggunaan minyak biji bunga matahari sebagai anti-acne dengan cara mengaplikasikannya secara langsung pada muka. Penggunaan ini dinilai kurang nyaman, tidak praktis, dan tidak stabil, sehingga untuk meningkatkan kenyamanannya dan kepraktisannya dibuat dalam bentuk sediaan krim. Pada penelitian ini akan dikembangkan 4 formula sediaan krim menggunakan desain faktorial dengan variasi 2 level konsentrasi emulgator, yaitu gliseril monostearat dan setil alkohol. Konsentrasi emulgator yang digunakan adalah 6\% dan 9\% untuk gliseril monostearat, serta 1\% dan 3\% untuk setil alkohol. Sediaan krim yang telah terbentuk dievaluasi baik secara fisika, kimia, maupun efektifitasnya terhadap bakteri Propionibacterium acnes secara invitro. Hasil evaluasi dari keempat sediaan krim anti-acne minyak biji bunga matahari kemudian dianalisis menggunakan desain faktorial.

\section{METODE PENELITIAN}

\section{Bahan}

Minyak biji bunga matahari, propilen glikol, gliseril monostearat, natrium lauril sulfat, metil paraben, propil paraben, setil akohol, paraffin liquid, $\alpha$ tokoferol, air suling, larutan dapar, DMSO, kaldu pepton, metilen blue, nutrient agar, larutan pengencer $\mathrm{NaCl}$, biakan bakteri Propionibacterium acnes.

\section{Peralatan}

Alat-alat gelas laboratorium, alat-alat volumetrik, refraktometer, timbangan analitik, oven, $\mathrm{pH}$ meter, viskometer brookfield (DV-II+ Pro), stirrer, gelas objek, cover glass dengan pengukur, jangka sorong, alat uji daya sebar, piknometer, termometer, autoklaf, vortex mixer, Laminar Air Flow Cabinet,inkubator, waterbath, mikroskop, lampu spiritus, rak tabung, tabung reaksi, cawan petri, jarum ose, tabung sentrifugal, sentrifugator, penetrometer. 


\section{Prosedur}

Penentuan nilai Konsentrasi Hambat Minimum (KHM) minyak biji bunga matahari

Dibuat larutan induk minyak biji bunga matahari dalam konsentrasi 2,5\%.Dari larutan induk, dibuat larutan uji minyak biji bunga matahari dengan konsentrasi 2,0\%; 1,5\%; $1,0 \% ; 0,5 \% ; 0,25 \% ; 0,125 \%$. Ke dalam tabung berisi $5 \mathrm{~mL}$ larutan uji pada masing-masing konsentrasi, ditambahkan $0,5 \mathrm{~mL}$ suspensi bakteri, divortex, kemudian diinkubasi pada suhu $37^{\circ} \mathrm{C}$ selama 24 jam. Diperoleh konsentrasi terendah yang dapat menghambat mikroba yang merupakan Konsentrasi Hambat Minimum (KHM) yang akan digunakan sebagai dosis minyak biji bunga matahari dalam formulasi sediaan krim.

\section{Optimasi kecepatan dan waktu pengadukan sediaan krim}

Optimasi kecepatan dan waktu pengadukan sediaan krim dilakukan untuk menentukan kecepatan dan waktu pengadukan yang optimal bagi sediaan krim minyak biji bunga matahari, sehingga diperoleh sediaan krim yang homogen dan tidak berbusa.

\section{Evaluasi fisika, kimia, dan efektivitas sediaan}

Sediaan krim dilakukan evaluasi organoleptik, homogenitas, tipe krim, viskositas, sifat alir, daya sebar, ukuran globul, sentrifugasi, $\mathrm{pH}$, serta efektivitas secara invitro dengan menganalisis nilai Diameter Daerah Hambat (DDH) dari sediaan krim terhadap bakteri Propionibacterium acnes.

\section{Analisis data menggunakan desain faktorial}

Analisis statistik digunakan untuk melihat pengaruh dari gliseril monostearat, setil alkohol, dan interaksi antara kedua emulgator tersebut terhadap sediaan krim minyak biji bunga matahari. Data hasil evaluasi dianalisis menggunakan analisis desain faktorial.

\section{HASIL PENELITIAN DAN PEMBAHASAN}

\section{Nilai KHM minyak biji bunga matahari}

Minyak biji bunga matahari ditentukan nilai KHM dengan metode dilusi cair. Nilai KHM yang diperoleh adalah 1,5\%.

\section{Organoleptik, homogenitas, tipe krim, dan sentrifugasi}

Pada sediaan krim minyak biji bunga matahari maupun sediaan blanko diperoleh hasil sediaan krim tipe M/A berwarna putih, tidak berbau dengan tekstur lembut, homogen, dan tidak adanya pemisahan antar fase setelah sentrifugasi

\section{Distribusi ukuran globul dan sifat alir}

Dari grafik hubungan antara ukuran globul dengan jumlah globul diperoleh kurva yang memenuhi hukum distribusi normal. Hal tersebut dapat dilihat dari bentuk grafik yang hampir menyerupai lonceng. Distribusi ukuran globul pada sediaan krim dapat mempengaruhi stabilitasnya. Jika suatu sediaan krim memiliki distribusi ukuran globul yang tidak merata, kecepatan sedimentasi semakin tinggi, sehingga sediaan krim yang dihasilkan menjadi mudah rusak.Grafik hubungan antara shearing stress dan rate of shear menunjukkan bahwa baik blanko maupun formula memiliki sifat alir tiksotropi plastis. Hal ini dapat dilihat dengan adanya kurva naik pada sebelah kiri dan kurva menurun pada sebelah kanan. Dari kurva tersebut dapat disimpulkan bahwa sediaan krim membutuhkan tekanan tertentu agar dapat mengalir karena kurva tidak mulai dari titik $(0,0)$. Sistem tiksotropi memiliki ciri-ciri dengan peningkatan tekanan geser, maka viskositas menurun 
dan viskositas sediaan tersebut akan kembali seperti semula jika dibiarkan selama jangka waktu tertentu.

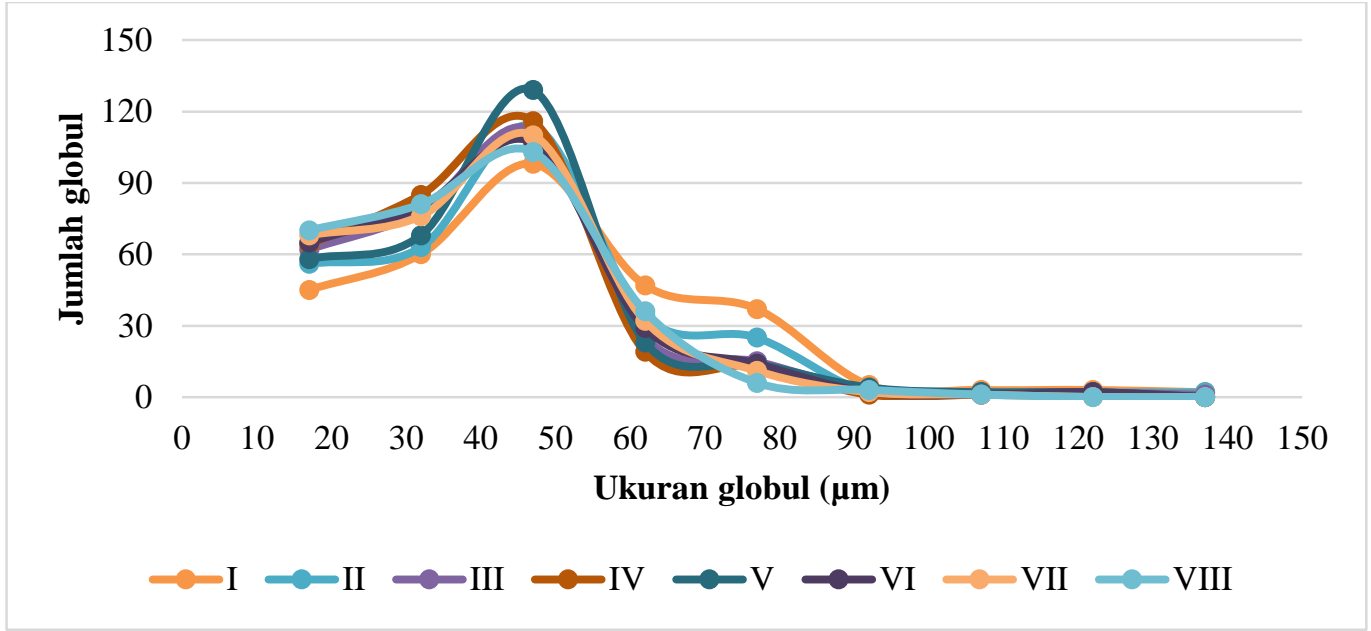

Grafik 1. Hubungan Antara Ukuran Globul Dengan Jumlah Globul

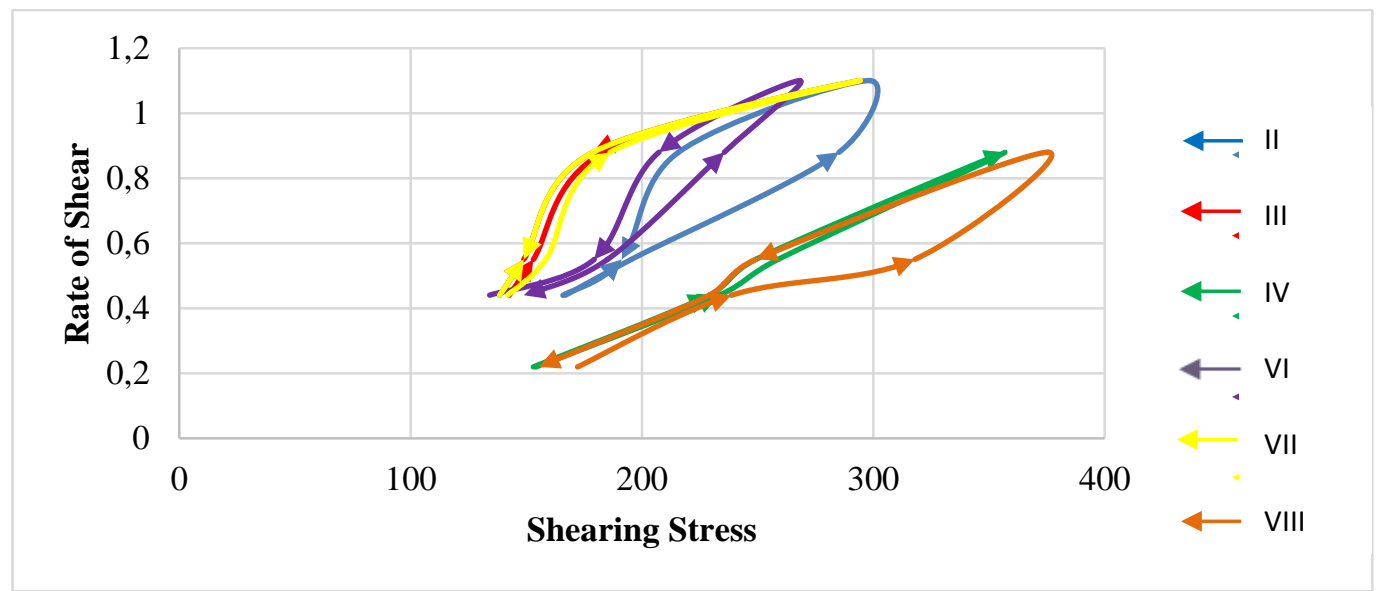

Grafik 2. Hubungan Antara Shearing Stress Dengan Rate of Shear

\section{Hasil analisis dengan desain faktorial}

Tabel 1. Hasil analisis dengan desain faktorial

\begin{tabular}{ccccc}
\hline No. & Respon & GMS & Setilalkohol & $\begin{array}{c}\text { Interaksi antara GMS } \\
\text { dan setil alkohol }\end{array}$ \\
\hline 1 & pH & $-0,157$ & 0,05 & 0,0033 \\
2 & Dayasebar & $-22,86$ & $-9,62$ & 2,29 \\
3 & Konsistensi & 28,223 & 10,510 & $-10,210$ \\
4 & DDH & $-0,250$ & $-15,533$ & 0,250 \\
5 & Viskositas & 8894,2 & 18464,5 & 819,2 \\
6 & Ukuranglobul & $-9,915$ & $-4,872$ & $-0,645$ \\
\hline
\end{tabular}

\section{a. Gliseril monostearat}


Peningkatan konsentrasi gliseril monostearat menurunkan $\mathrm{pH}$,dayasebar, DDH,dan ukuran globul, tetapi meningkatkan konsistensi dan viskositas sediaan krim.

\section{b. Setil alkohol}

Peningkatan konsentrasi setilalkohol menurunkan daya sebar, DDH, dan ukuran globul, tetapi meningkatkan $\mathrm{pH}$,konsistensi, dan viskositas sediaan krim.

\section{c. Interaksi antara gliseril monostearat dan setilalkohol}

Peningkatan konsentrasi kedua emulgator menurunkan konsistensi dan ukuran globul, tetapi meningkatkan $\mathrm{pH}$, daya sebar, $\mathrm{DDH}$, dan viskositas sediaan krim.

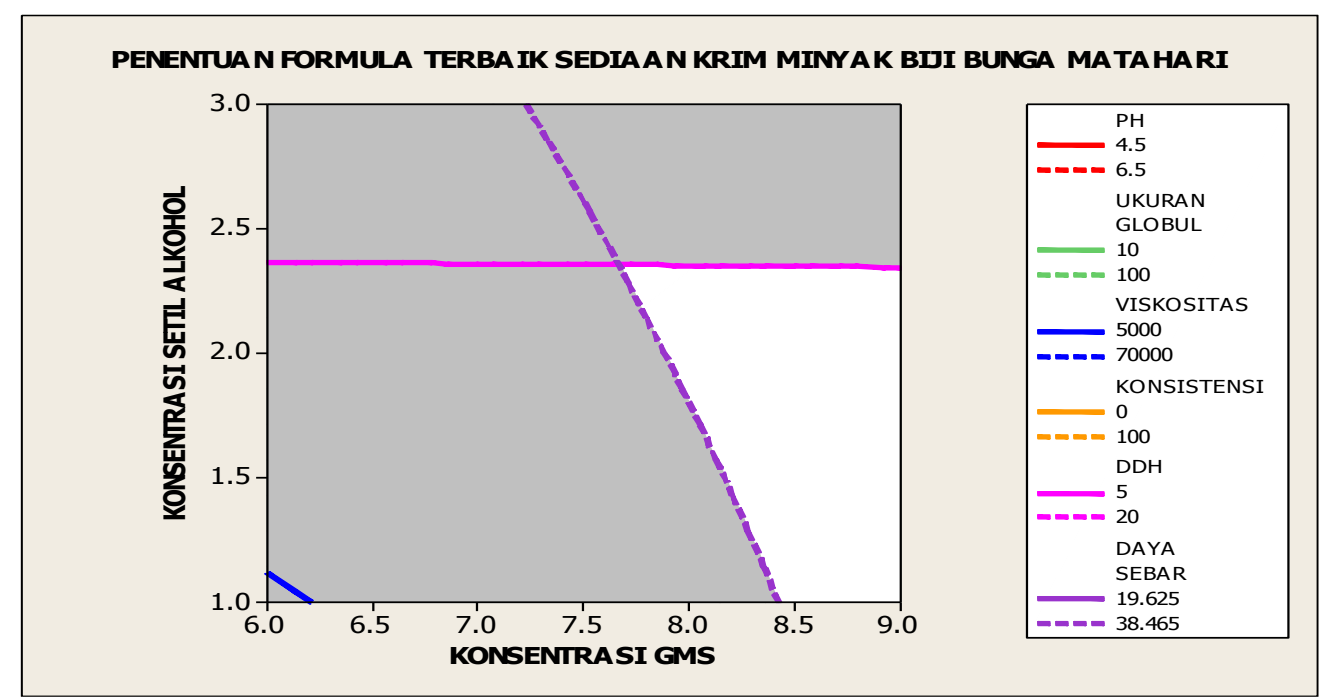

Grafik 3. Penentuan formula terbaik sediaan krim minyak biji bunga matahari

\section{KESIMPULAN}

1. Minyak biji bunga matahari (Helianthus annuusL.) memiliki nilai Konsentrasi Hambat Minimum (KHM) sebesar 1,5\%, sehingga berpotensi sebagai anti-acne.

2. Formula sediaan krim M/A minyak biji bunga matahari yang terbaik baik secara fisika maupun kimia terdapat pada formula III yang memiliki konsentrasi gliseril monostearat sebesar 9\% dan setilalkohol sebesar 1\%. Formula III ini memilikiciri-ciri berwarna putih, tidak berbau, dan tekstur lembut dengan nilai yield value sebesar 90,77 dyne $/ \mathrm{cm}^{2}$, memiliki ukuran globul sebesar 59,90 $\mu \mathrm{m}$, viskositas sebesar 32705,33 cP dengan sifat alir tiksotropi plastis, dan kemampuan menyebar sebesar $33,62 \mathrm{~cm}^{2}$.

3. Sediaan krim minyak biji bunga matahari pada formula III efektif sebagai anti-acne dengan nilai Diameter Daerah Hambat (DDH) sebesar 15,28 mm dimana pada nilai tersebut tergolong dalam klasifikasi antibakteri yang kuat.

\section{DAFTAR PUSTAKA}

1. Fitzpatrick TB, Eisen AZ, Wolff K, Freedberg IM, Austen KF., 2008. Dermatology in General Medicine. $7^{\text {th }}$ Ed. New York: McGraw-Hill. h. 690-703.

2. Loyd VD, Nicholas GP, HC. Ansel., 2005. Ansel's Pharmaceutical Dosage Forms and Drug Delivery Systems. Eight Edition. Philadelphia: Lippincott Williams \& Wilkins.

3. Michael J Pelczar Jr., 2005. Dasar-Dasar Mikrobiologi 2. Jakarta: UI-Press. 
4. Oprica C., 2004. Antibiotic-Resistant Propionibacterium Acnes on the Skin of Patient with Moderate to Severe Acne. Journal of Pharmacology. h. 155-64. 